\title{
Overexcitabilities and Psychological Issues among Gifted Learners at Higher Education Level
}

\section{Yee Siew Kuan, Salleh Amat \& Mohd Izwan Mahmud}

To Link this Article: http://dx.doi.org/10.6007/IJARBSS/v11-i12/11763

DOI:10.6007/IJARBSS/v11-i12/11763

Received: 04 October 2021, Revised: 06 November 2021, Accepted: 25 November 2021

Published Online: 13 December 2021

In-Text Citation: (Kuan et al., 2021)

To Cite this Article: Kuan, Y. S., Amat, S., \& Mahmud, M. I. (2021). Overexcitabilities and Psychological Issues among Gifted Learners at Higher Education Level. International Journal of Academic Research in Business and Social Sciences, 11(12), 260-267.

\section{Copyright: @ 2021 The Author(s)}

Published by Human Resource Management Academic Research Society (www.hrmars.com)

This article is published under the Creative Commons Attribution (CC BY 4.0) license. Anyone may reproduce, distribute, translate and create derivative works of this article (for both commercial and non0-commercial purposes), subject to full attribution to the original publication and authors. The full terms of this license may be seen at: http://creativecommons.org/licences/by/4.0/legalcode

Full Terms \& Conditions of access and use can be found at http://hrmars.com/index.php/pages/detail/publication-ethics 


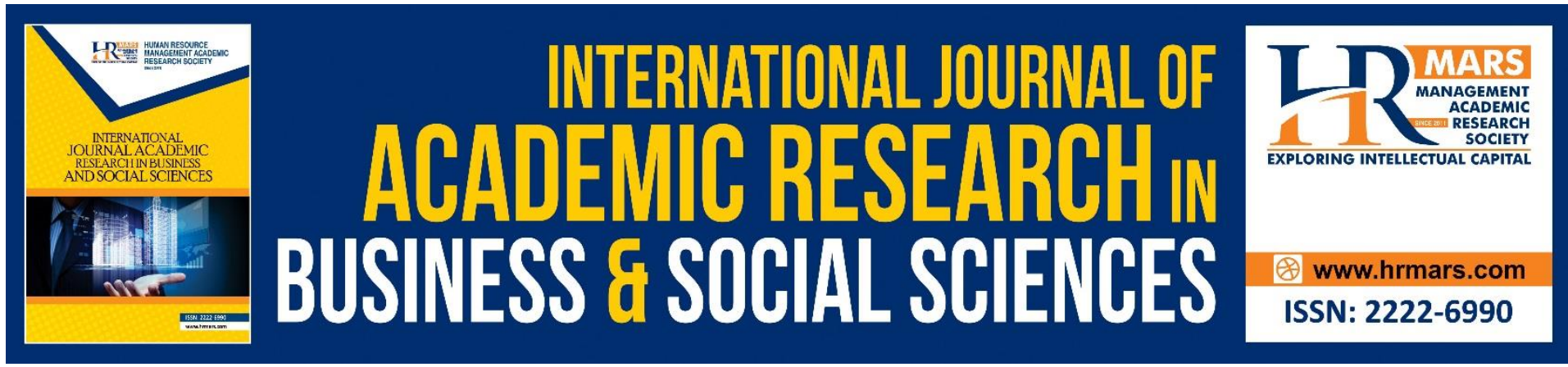

\title{
Overexcitabilities and Psychological Issues among Gifted Learners at Higher Education Level
}

\author{
Yee Siew Kuan, Salleh Amat \& Mohd Izwan Mahmud
}

Faculty of Education, Universiti Kebangsaan Malaysia, 43600 Bangi, Selangor, Malaysia

Email: sallehba@ukm.edu.my

\begin{abstract}
Gifted learners are more advance as compared to learners of their chronological age. Along with this advancement, these learners faced asynchronous development that makes them has the characteristics of sensitive, perfectionistic, deep reflective thinking and moral issues that affect them more deeply. Apart from the asynchronous development, these learners also showed the high intensity of having overexcitabilities. Overexcitability is the mode of experiencing with heightened sensitivity. Studies found that gifted learners who experience overexcitability are more likely to be misunderstood and alienated than those who do not have these sensitives. Thus, this study aims to discuss gifted learners' overexcitabilities and psychological issues at the higher education level. Past research shows a relationship between overexcitabilities with perfectionism, insomnia, fear of the unknown, death anxiety, and depression. By helping gifted learners identify psychological issues earlier, counsellors should be able to help the student find meaning and purpose in their daily activities. Therefore, future research should focus on how counselling gifted learners about overexcitability will be able to overcome their limitations so they can reach tremendous potential and achieve higher levels of development.
\end{abstract}

Keywords: Overexcitability, Psychological Issues, Gifted Learners, Higher Education, Counselling

\section{Introduction}

Gifted learners learn faster, process information more deeply and require less repetition in order to master a subject as compared to their peers (Coleman \& Cross, 2001), yet they face psychological issues just like their peers. Giftedness seems to add complexity to the development of gifted learners who face unique psychological issues (Neihart et al., 2015). Along with the gifted learners' capability, they experience asynchronous development that causes them to have characteristics such as sensitivity, perfectionism, deep thinking and moral issues that affect them deeply. Past study focused on overexcitability (Razak et al., 2021; Zanariah et al., 2019; Mendaglio, 2021) and psychological issues (Cross \& Cross, 2015), but no studies have focused on how overexcitability impacts psychological issues among gifted learners especially at higher education level. Thus, this study aims to discuss the overexcitabilities and psychological issues of gifted learners. 


\section{Literature Review \\ Overexcitability}

Gifted individuals are often associated with extraordinary excitement (Szymanski \& Wrenn, 2019; Alias et al., 2013; Zanariah et al., 2019; Mendaglio, 2012). Kazimierz Dabrowski in his book Positive Disintegration (1964) has introduced the Theory of Positive Disintegration which emphasizes on three components namely individual abilities, extraordinary excitement (also use interchangeably with overexcitability in this article) and the third factor that influences the development of an individual's personality. Individual ability is often used in defining a person's intelligence, where it is also seen as the cognitive ability to learn something quickly (Szymanski \& Wrenn, 2019). Extraordinary excitement is seen as energising intelligence and talent where the individual is more sensitive to environmental stimuli (Szymanski \& Wrenn, 2019) while the third factor is the capacity for a person to direct himself for emotional development (Daniels \& Piechowski, 2009). According to Dabrowski (1972), there are five domains of extraordinary excitement (OE), namely psychomotor, intellectual, emotional, imaginative and sensory.

\section{Psychological Issues}

Several studies have shown that gifted youth experience psychological issues such as mood disorders (Bénony et al., 2007) and anxiety (Harrison \& Van Haneghan, 2011). Gifted learners face exciting psychological challenges due to their extraordinary abilities (Cross \& Cross, 2015). The life experiences of these gifted learners may be different from the majority of their peers and the community (Coleman, 2012). When professionals are unaware of gifted individuals' social and emotional needs, professionals can inadvertently inflict more harm than good (Cross \& Cross, 2015). Cross and Cross (2015) also identified that gifted individuals may be uniquely at risk for issues such as depression, anxiety, suicidality, and unhealthy perfectionism. Procrastination, being perceived as not perfect enough and failing to live up to expectations may cause unhealthy perfectionism (Abu Yazid \& Brody, 2021)Studies have not shown linkage of genetic and intelligence causing mood disorders (Webb et al., 2007). While, Cross and Cross (2015) mentioned that gifted individuals faced individual, social and environmental pressures that may contribute to psychological issues. Gifted learners often receive conflicting messages as opposed to the meaning and value of intelligence (Cross \& Cross, 2012). As stated by Rimm (2002), being too smart or mastering a concept too fast can cause isolated effect, leaving an individual feels different from their peer as academic achievement is usually celebrated. While, according to Cross (2012), Cross and Cross (2015) and Rimm (2002), affective reactions such as anxiety and/or depression may reach clinical levels when combined with boredom, not well understood feelings, and unable to recognize environment changes. This worsens when the individual feels helpless and constantly hiding their true self, it will then may lead to suicidality (Cross \& Cross, 2015). The mixed message of giftedness can also be attributed to perfection, a phenomenon that can bring benefits (i.e., leads to perseverance, resilience, and continuous effort with achievement) or detrimental (Webb et al., 2007).

\section{Research Methodology}

This study uses meta-analysis to analyse research that has been conducted in relevance to overexcitabilities and psychological issues. This method is to comprehensively identify all relevant primary studies by using the terms overexcitabilities, psychological issues, gifted learners, counselling, and higher education through the literature search from 2011 till 2021 
using the databases from Journal for the Education of the Gifted, Gifted and Talented International, Gifted Child Quarterly, and Google Scholar.

\section{Results}

\section{Research Design}

Table 1 shows the frequencies and percentages of research designs and methods used in the 20 studies assessed in this investigation. The articles were analysed systematically to extract information related to overexcitabilities and psychological issues. Majority of the research studies were quantitative (70\%), while other designs each accounted for only $30 \%$ of the total sample.

Table 1. Statistics of Research Design

\begin{tabular}{lll}
\hline Research design & $\mathbf{n}$ & $\mathbf{\%}$ \\
\hline Quantitative & 14 & 70.00 \\
Mixed-Method & 1 & 5.00 \\
Case Study & 1 & 5.00 \\
Meta-Analysis & 4 & 20.00 \\
\hline
\end{tabular}

$\mathrm{n}=20$

\section{Psychological Issues}

The 20 articles obtained from Journal for the Education of the Gifted, Gifted and Talented International, Gifted Child Quarterly, and Google Scholar were extracted according to the type of psychological issues shown in Table 2. Results show that suicidal ideation/depression $(26.92 \%)$ is the most frequently studied field, followed by anxiety $(23.08 \%)$, perfectionism (19.23\%), and stress (11.53\%).

Table 2. Statistics of Psychological Issues

\begin{tabular}{lll}
\hline Type of Psychological Issues & $\mathbf{n}$ & \% \\
\hline Perfectionism & 5 & 19.23 \\
Insomnia & 1 & 3.85 \\
Anxiety & 6 & 23.08 \\
Suicidal Ideation / Depression & 7 & 26.92 \\
ADHD & 2 & 7.69 \\
OCD / Mania / Eating Disorder & 1 & 3.85 \\
Cyberbullying / Internet Addiction & 1 & 3.85 \\
Stress & 3 & 11.53 \\
\hline
\end{tabular}

$n=26$

\section{Research Samples}

Table 3 shows the research samples that have been studied for both overexcitabilities and psychological issues. A total of $66.68 \%$ of studies have been done towards gifted adolescents. However, there is a limited study that combined both overexcitabilities and psychological issues among gifted adolescents. 
Table 3. Statistics of Research Samples

\begin{tabular}{lll}
\hline Research Samples & $\mathbf{n}$ & \% \\
\hline Adults from General Population & 1 & 4.76 \\
Creative Adolescents & 2 & 9.52 \\
Gifted Adolescents & 14 & 66.68 \\
Adolescents from General Population & 2 & 9.52 \\
Academically Talented Undergraduate & 1 & 4.76 \\
Students & & \\
Undergraduate Students & 1 & 4.76 \\
\hline
\end{tabular}

$n=21$

\section{Discussion}

\section{Research Design}

This research produced several important findings in relevance to overexcitabilities and psychological issues based on articles from the Journal for the Education of the Gifted, Gifted and Talented International, Gifted Child Quarterly, and Google Scholar for the period of 2011 till 2021. Based on the results shown in Table 1, it can be concluded that most of the studies in relevance to overexcitabilities and psychological issues are conducted quantitatively. Only $30 \%$ of the studies were conducted using research design apart of quantitative. Thus, it is suggested future research should be focusing on methodology apart from quantitative.

\section{Psychological Issues}

Results in Table 2 shows the types of psychological issues commonly studied among gifted individuals. Although suicidal ideation/depression is frequently studied, findings were not consistent where some studies found that suicidal ideation was below average (Chen et al., 2020), while some studies show moderate/high depression level (Simin et al., 2020; Yazid et al., 2019). Besides suicidal ideation/depression, perfectionism is frequently studied (Cross et al., 2018; Lee et al., 2020; Olton-Weber et al., 2020; Perrone-McGovern et al., 2015). However, limited studies were done was related to overexcitability and psychological issues among gifted individuals. Hence, it is recommended for future studies to study overexcitability and various psychological issues among gifted individuals.

\section{Research Samples}

Of the 20 articles used in this study, 66.68\% studied gifted adolescents; however, none of the study relate overexcitability and psychological issues among gifted students at the higher education level. Though some studies discuss overexcitability and perfectionism among gifted adolescents (Mofield \& Parker, 2015), the scope of the study for psychological issues is limited. Thus, it is recommended that future studies involve gifted students at higher education level as the study sample.

\section{Conclusion}

A part of identifying gifted learners, the psychologist's job is to meet the psychosocial needs, counselling and linking between students, schools and parents (Robinson, 2002). According to Colangelo and Assouline (2000), schools should be aware of the uniqueness of gifted learners in dealing with developmental challenges and school or family environment that is likely to convey misleading information and give high hopes for success. According to Aslan and Yukay-Yuksel (2018), gifted and talented individuals often hide their socio-emotional 
issues, and psychologists need to be careful to express their concerns and needs. Furthermore, gifted and talented individuals can be supported through informal counselling approaches such as books and films that focus on gifted and talented individuals, inspiring them to be more enthusiastic and strive to develop their talents. Thus, this study may help gifted educational practitioners in providing support and needs for gifted learners. Future research should focus on how counselling gifted learners about overexcitability will help them break through to higher levels where there is complete self-acceptance, which may help them to reach great potential to move toward higher levels of development.

\section{Acknowledgement}

Funding: This study was supported by the Geran Fakulti Pendidikan, Universiti Kebangsaan Malaysia (GG-2020-022 and GG-2019-078).

\section{References}

Alias, A., Rahman, S., Majid, R. A., \& Yassin, S. F. M. (2013). Dabrowski's overexcitabilities profile among gifted students. Asian Social Science, 9 (16), 120-125.

Aslan, S., \& Yukay-Yuksel, M. (2018). An investigation of the relationship between social behavior characteristics and self-perceptions of gifted children in primary school. Journal for the Education of Gifted Young Scientists, 6(1), 17-42.

Bakar, A. Y. A., \& Brody, L. E. (2021). Handbook of Giftedness and Talent Development in the Asia-Pacific (Springer International Handbooks of Education). (S. R. Smith, Ed.) (1st ed. 2021 ed.). Springer.

Bénony, H., Van Der Elst, D., Chahraoui, K., Bénony, C., \& Marnier, J. P. (2007). Link between depression and academic self-esteem in gifted children. L'Encephale, 33(1), 11-20.

Chen, X., Fan, X., Wu, J., \& Cheung, H. Y. (2020). Factors Related to Suicidal Cognitions of Academically gifted students in the Chinese social-cultural context: an exploratory study. Gifted Child Quarterly, 64(3), 204-218.

Colangelo, N., \& Assouline, S. G. (2000). Counseling gifted students. In. K. A. Heller, F. J. Mönks, R. J. Sternberg, \& R. S. Subotnik (Eds.). International handbook of giftedness and talent (Eds. 2) (pp. 595-607). Oxford, UK: Pergamon.

Coleman, L. J. \& Cross, T. L. (2001). Being gifted in school: An introduction to development, guidance, and teaching. Waco, TX: Prufrock Press, Inc.

Coleman, M. R. (2012). Response to Intervention (RtI) approaches to identification practices within gifted education. In C. Callahan \& H. Hertberg-Davis (Eds.), Fundamentals of Gifted Education: Considering Multiple Perspectives (pp.152-158). New York, NY: Taylor \& Francis.

Cross, J. R., \& Cross, T. L. (2015). Counseling the gifted: past, present, and future directions. Journal of Counseling \& Development, 93(2), 133-142.

Cross, T. \& Cross J. (2012). Handbook for counselors serving students with gifts and talents. Waco, TX; Prufrock Press Inc.

Cross, T. L., Cross, J. R., Mammadov, S., Ward, T. J., Neumeister, K. S., \& Andersen, L. (2018). Psychological heterogeneity among honors college students. Journal for the Education of the Gifted, 41(3), 242-272.

Dabrowski, K. (1964). Positive disintegration. Boston: Little Brown.

Dabrowski, K. (1972). Psychoneurosis is not an illness. London:Gryf. 
Daniels, S., \& Piechowski, M. M. (2009). Embracing intensity: overexcitability, sensitivity and the developmental potential of the gifted. In S. Daniels, \& M. M. Piechowski (Eds.), Living with Intensity. USA: Great Potential Press.

Harrison, G. E., \& Van Haneghan, J. P. (2011). The gifted and the shadow of the night: Dabrowski's overexcitabilities and their correlation to insomnia, death anxiety, and fear of the unknown. Journal for the Education of the Gifted, 34(4), 669-697.

Lee, L. E., Rinn, A. N., Crutchfield, K., Ottwein, J. K., Hodges, J., \& Mun, R. U. (2020). Perfectionism and the imposter phenomenon in academically talented undergraduates. Gifted Child Quarterly, 001698622096939.

Mendaglio, S. (2012). Overexcitabilities and giftedness research. Journal for the Education of the Gifted, 35(3), 207-219.

Mendaglio, S. S. (2021). Overexcitability and giftedness research: Whose constructs are being investigated and how? In Smith, S. R. (Eds.) Handbook of giftedness and talent development in the Asia-Pacific. Singapore: Springer International Handbooks of Education.

Mofield, E. L., \& Peters, P. M. (2015). The relationship between perfectionism and overexcitabilities in gifted adolescents. Journal for the Education of the Gifted, 38(4), 405-427.

Neihart, M., Pfeiffer, S. I., \& Cross, T. L. (2015). The social and emotional development of gifted children: What do we know? (Eds. 2). Waco, TX: Prufrock Press.

Ogurlu, U., Yalin, H. S., \& Yavuz Birben, F. (2018). The relationship between psychological symptoms, creativity, and loneliness in gifted children. Journal for the Education of the Gifted, 41(2), 193-210.

Olton-Weber, S., Hess, R., \& Ritchotte, J. A. (2020). Reducing levels of perfectionism in gifted and talented youth through a mindfulness intervention. Gifted Child Quarterly, 64(4), 319-330.

Paek, S. H., Abdulla, A. M., \& Cramond, B. (2016). A meta-analysis of the relationship between three common psychopathologies-ADHD, anxiety, and depression-and indicators of little-c creativity. Gifted Child Quarterly, 60(2), 117-133.

Perrone-McGovern, K. M., Simon-Dack, S. L., Beduna, K. N., Williams, C. C., \& Esche, A. M. (2015). Emotions, cognitions, and well-being: The role of perfectionism, emotional overexcitability, and emotion regulation. Journal for the Education of the Gifted, 38(4), 343-357.

Piirto, J., \& Fraas, J. (2012). A mixed-methods comparison of vocational and identified-gifted high school students on the overexcitability questionnaire. Journal for the Education of the Gifted, 35(1), 3-34.

Razak, A. Z. A., Bakar, A. Y. A., Surat, S., \& Majid, R. A. (2021). Perfectionism and Overexcitability: Uniqueness or Lack of Socioemotional Development of Gifted and Talented Students? Journal of Legal, Ethical and Regulatory Issues, 24(1), 1-8.

Rimm, S. (2002). Peer pressures and social acceptance of gifted students. In Neihart, M., Reis, S. M., Robinson, N. M. \& Moon, S. M. (Eds.). The social and emotional development of gifted children. Washington: Prufock Press Inc.

Robinson, E. L. (2002). What is the school psychologist's role in gifted education? Gifted Child Today, 25(4), 34-37.

Rollins, M. R., \& Cross, T. L. (2014). Assessing the psychological changes of gifted students attending a residential high school with an outcome measurement. Journal for the Education of the Gifted, 37(4), 337-354. 
Simin, N., Sa'ari, C. Z., Muhsin, S. B. S., Joli, N. S., \& Abidin, M. H. Z. (2020). Depression anxiety stress among gifted and talented students in Malaysia during the Movement Control Order (MCO). Journal of Critical Reviews, 7(11), 614-616.

Sureda Garcia, I., López Penádes, R., Rodríguez Rodríguez, R., \& Sureda Negre, J. (2020). Cyberbullying and internet addiction in gifted and nongifted teenagers. Gifted Child Quarterly, 64(3), 192-203.

Szymanski, A. T. \& Wrenn, M. (2019). Growing up with intensity: Reflections on the lived experiences of intense, gifted adults. Roeper Review, 41 (4), 243-257.

Vuyk, M. A., Kerr, B. A., \& Krieshok, T. S. (2016). From overexcitabilities to openness: Informing gifted education with psychological science. Gifted and Talented International, 31(1), 59-71.

Vuyk, M. A., Krieshok, T. S., \& Kerr, B. A. (2016). Openness to experience rather than overexcitabilities. Gifted Child Quarterly, 60(3), 192-211.

Webb, J. T., Gore, J. L., Amend, E. R., \& DeVries, A. R. (2007). A parent's guide to gifted children. Scottsdale, AZ: Great Potential Press.

Winkler, D., \& Voight, A. (2016). Giftedness and overexcitability: Investigating the relationship using meta-analysis. Gifted Child Quarterly, 60(4), 243-257.

Yazid, A. F., Khan, A. R. K. R. A., Asmuje, N. F., Zainun, A., \& Theis, N. A. (2019). Correlation study of intelligence with mental health issues among gifted and talented students. Malaysian Journal of Youth Studies, 2, 98-110.

Zanariah, A., Surat, S., Rahman, S. A., \& Majid, R. A. (2019). Keterujaan luar biasa dan implikasinya terhadap pelajar pintar dan berbakat di Malaysia. Journal of Islamic Social Sciences and Humanities, 20 (2), 116-130. 